\title{
SME Financing and Entrepreneurship Development in Bangladesh: An Impact Analysis
}

\author{
Dr. Kamrul Hasan \\ Associate Professor, Faculty of Business Administration, \\ American International University Bangladesh (AIUB)
}

\begin{abstract}
The current study has examined 41 SMEs financed by BASIC Bank to evaluate the impact on entrepreneurship development. The study evaluates the entrepreneurship development of the sample enterprises through variables like, sales growth, return on investment, assets turnover and profit margin. The study found that by taking loans from BASIC Bank the sample enterprises have been able to increase their sales, profit, assets and the like. Thus, the findings of the study show that firms that receive bank loans can significantly increase their performance. The regression analysis also depicted the significance of the impact of financing on entrepreneurship development of selected SMEs. The study also highlighted several areas where BASIC bank's assistance programs create positive effect like, improved profitability, higher level of output, increased sales, increased productivity, increased employment and the like.
\end{abstract}

Keywords: Productivity, Profitability, Financial assistance, Entrepreneurship Development.

DOI: $10.7176 / \mathrm{EJBM} / 11-4-06$

\section{Introduction}

This study presents the entrepreneurship development of selected SMEs and assesses the impact of financial assistance upon the growth and development of the SMEs under study. Economic theory suggested that access to loans should lead to higher profits of SME primarily in two ways: First, funds are available for working capital and second, accumulation of modern technical equipment, which is made feasible by the availability of the funds. The significant relationship between loans and profitability might be because SMEs with larger amount of loans from commercial banks are more likely to use new technology for production, which in turn will increase the profit of the firms. Similarly, more capital base will also increase turnover and consequently profit. Therefore, a vital element for entrepreneurship to thrive is the availability of capital for start-ups and growing business.

\section{Review of Literature:}

Chowdhury and Alam (2017) investigated 86 SMEs and found that, size and age of the firm, education and skills of the owner's, high interest rate, lack of collateral security and corruption by bank officials are the key barriers in SME loan. Bosri (2016) depicted that, the success rate of SME financing is very high but disbursement of SME loan is low than industrial loan. Taiwo et. al.,(2016) recommended that, Government should formulate policies for the development of SMEs by assisting throughs soft loans at low interest rate and other fiscal incentives in order to enhance the socio-economic development of the economy. Akter and Alauddin (2016) found that, the PCB's are reluctant to finance SMEs due to avoid high risk, lack of collateral, proper documentation and monitoring etc. Haider and Akter (2014) opined that, the financing gap of middle segment of SMEs are acute. The study suggests that, in an early stage Government has to subsidize the development of SMEs. Sharma S.C. (2012) observed that the institutions not only provide financial assistance but also provide other support such as assistance for marketing the product, ensuring quality, training of workers, assistance in up-gradation of technology, develop industrial estates and the like. Mamun et al. (2013) found that SME faced major problems viz., high interest rate, complexity of documentation, non-availability of loan in due time, non-availability of required amount, banker's reluctance and negligence and the like. Alam and Ullah (2006) identified lack of medium to long term credit, limited access to market opportunities, technology and expertise and business information. Bose and Uddin (2013) found that business plan, channel of distribution, management skills and Government support are identified statistically significant in determining success of SMEs in Khulna City. Somoye (2013) evaluates the impact of finance on entrepreneurship growth in Nigeria and found that, finance, interest rate are significant in entrepreneurship in Nigeria. Pandey and Ansari (2012) examined credit problem, lack of collateral, lack of training, delay in obtaining finance or inadequate finance, high rate of interest, negative attitude are significant. Islam et al. (2011) The results of the analysis showed that SMEs those are in operation for longer period have been more successful in comparison to those who have been in operation for a shorter period. Akterujjaman (2010) revealed that SMEs are not preparing proper financial statements which creates problem for the bank judging financial standings, profitability and credibility. Jahur (2010) found that, factors responsible for success of entrepreneurs of SMEs Relationship Factor and Organization factor in order magnitude. Solaiman and Chowdhury (2010) revealed that dynamic and effective market management of small industries ensures better working environment which in turn may contribute in the 
process of development of an individual as an entrepreneur. Ahmed and Chowdhury (2009) found that the performance of SMEs of Bangladesh, specially in terms of employee turnover rate, quality assurance, allocation of funds, marketing activities was below the international standard. Afrin et al. (2008) found that the financial management skill and the group identity of the borrowers have a direct and significant relationship with the development of women entrepreneurship through micro credit program. Grover and Singla (2012) showed that there exists a positive relationship between extent of bank credit and growth of small and micro enterprises represented by sales growth, number of SMEs and productivity. Obamuyi (2010) which suggests that access to loans should lead to higher profits. Davis and Gaburici (2001) suggested that banks loan could lead directly to additional capital inputs, which tend to lead to better changes of survival.

\section{Research Design:}

Both primary and secondary data have been used in the study. Primary data have been collected through structured questionnaire from 41 SME's selected randomly in different sectors like food \& allied, textile, paper \&printing, chemical \& pharmaceuticals and engineering and the like. Data have been analyzed through different descriptive and inferential statistical tools like average, growth rate, trend analysis, standard deviation, coefficient of variation, correlation \& regression analysis and presented in the form of table and graphs. Inferential statistical tools like ' $\mathrm{t}$ ' test and ' $\mathrm{f}$ ' test have been used to test the significance of the findings. The variables are sales growth, employment growth, value added per employee, net profit ratio, asset turnover and return on assets. The study evaluated the organizations performance of SMEs, those who are getting loans from BASIC Bank.

Regression Model: $\mathrm{Y}=\mathrm{A}+\beta_{1} \mathrm{X}_{1}+\beta_{2} \mathrm{X}_{2}+\beta_{3} \mathrm{X}_{3}+\beta_{4} \mathrm{X}_{4}+\beta_{5} \mathrm{X}_{5}+\mu_{c}$

Where, $\mathrm{Y}=$ Changes in sales growth, changes in employment growth, Changes in productivity and changes in profitability , $\mathrm{A}=$ Constant, $\beta_{1}=$ Co-efficient of $\mathrm{X}_{1}, \mathrm{X}_{1}=$ Loan to Total Asset, $\beta_{2}=$ Co-efficient of $\mathrm{X}_{2}$, $\mathrm{X}_{2}=\log ($ Asset $), \beta_{3}=$ Co-efficient of $\mathrm{X}_{3}, \mathrm{X}_{3}=$ No. of years of Operations, $\beta_{4}=$ C0efficient of $\mathrm{X}_{4}, \mathrm{X}_{4}=$ No. of customers , $\beta_{5}=$ Coefficient of $\mathrm{X}_{5}, \mathrm{X}_{5}=\mathrm{T}$-Bond Rate.

4. Objective of the Study: The main objective of the study is to critically evaluate the impact of SME financing on entrepreneurship development in Bangladesh.

\section{Findings and Analysis}

\subsection{Regression of Sales Growth against financial service:}

Table-1: Estimates of pooled Data of Step Wise Regression Model

\begin{tabular}{|c|c|c|c|c|c|}
\hline \multicolumn{6}{|c|}{ Model-I (Dependent variable: Sales growth) } \\
\hline Details & B & $\mathbf{S} / \mathbf{E}$ & t value & Sign & VIF \\
\hline Constant & 4.747 & .207 & 22.93 & $.002^{*}$ & \\
\hline Loan to total Asset & .75 & .112 & .67 & $.026^{* * *}$ & 1.44 \\
\hline Size & .175 & .114 & 1.053 & $.001^{*}$ & 1.48 \\
\hline Age & .31 & .23 & 1.34 & $.034^{* * *}$ & 1.35 \\
\hline Relationship banking & .21 & .13 & & .088 & 1.04 \\
\hline T-bond rate & .15 & & & & 1.33 \\
\hline F value & 7.617 & & & $.002^{*}$ & \\
\hline $\mathbf{R}^{2}$ & $56.85 \%$ & & & & \\
\hline Adjusted Ŕ ${ }^{2}$ & $55.3 \%$ & & & & \\
\hline
\end{tabular}

Note: Data have been compiled by the researcher

$* 1 \%$ level of significance, $* * 5 \%$ level of significance.

Table-1 shows a regression analysis of the sales growth of sample SMEs against independent variables. The table shows that the co-efficient of determination of the linear regression of the sales growth against the independent variable is explained by 56.85 percent of the variation for the sample SMEs. It is also revealed that the results of ' $F$ ' test and ' $t$ ' statistics were found highly significant. The parameter information indicates that the financial assistance (loan to total asset) is the main contributor with change in sales of the assisted firms under study.

5.2. Regression of employment growth against financial services: Table 2 shows a regression analysis of the employment growth of sample SMEs against loan variable. The table shows that the co-efficient of determination of the linear regression of the employment growth against the loan is explained by 41.5 percent of the variation for the sample SMEs. 
Table-2: Estimates of pooled Data of Step Wise Regression Model

\begin{tabular}{|c|c|c|c|c|c|}
\hline \multicolumn{6}{|c|}{ Model-I (Dependent variable: Employment growth) } \\
\hline Details & B & S.E & t value & Sign & VIF \\
\hline Constant & $\mathbf{1 . 8 4 7}$ & .207 & 6.067 & $.002^{*}$ & \\
\hline Loan to TA & .58 & .13 & .38 & .042 & 1.42 \\
\hline Size & .04 & .11 & .36 & .11 & 1.45 \\
\hline Age & .22 & .14 & 1.57 & $.001^{*}$ & 1.25 \\
\hline R. banking & .21 & .13 & 1.61 & .088 & 1.01 \\
\hline T-bond rate & .15 & .11 & 1.36 & .033 & 1.22 \\
\hline F value & 2.711 & & & $.002^{*}$ & \\
\hline $\mathbf{R}^{2}$ & $41.5 \%$ & & & & \\
\hline Adjusted $\mathbf{R}^{2}$ & $35.3 \%$ & & & & \\
\hline
\end{tabular}

Note: Data have been compiled by the researcher.

$* 1 \%$ level of significance.

It is revealed from the table-2 that the results of ' $F$ ' test and ' $t$ ' statistics were found highly significant. The parameter information shows that loan to total assets, contributed significantly to the relationship with change in employment of the assisted firms. This means that the loan variable is capable of influencing the employment growth.

5.3. Regression of productivity against financial service:

Table-3 shows a regression analysis of the productivity of SMEs against loan variable and other independent variable.

Table-3: Estimates of pooled Data of Step Wise Regression Model

\begin{tabular}{|c|c|c|c|c|c|}
\hline \multicolumn{6}{|c|}{ Model-I Dependent variable: Productivity } \\
\hline Details & B & S.E & t value & Sign & VIF \\
\hline Constant & 2.676 & .207 & 7.199 & $.002^{*}$ & \\
\hline Loan to T.A & .53 & .11 & 4.81 & $.001 * *$ & 1.24 \\
\hline Size & .04 & .114 & 1.053 & $.001^{*}$ & 1.58 \\
\hline Age & .22 & .23 & 1.83 & $.034^{* * *}$ & 1.25 \\
\hline R. banking & .21 & .13 & 1.62 & .088 & 1.04 \\
\hline T-bond rate & .15 & .11 & 1.36 & .022 & 1.33 \\
\hline F value & 7.617 & & & $.002^{*}$ & \\
\hline $\mathbf{R}^{2}$ & $62.3 \%$ & & & & \\
\hline Adjusted R' & $35.3 \%$ & & & & \\
\hline
\end{tabular}

Note: Data have been compiled by the researcher

$* 1 \%$ level of significance $; * * 5 \%$ level of significance

Table 3 shows a regression analysis of the productivity of SMEs against loan variable. The table shows that the co-efficient of determination of the linear regression of the productivity against the loan is explained by 62.3 percent of the variation for the sample SMEs. It is also revealed that the results of ' $F$ ' and ' $T$ ' statistics were found highly significant. The parameter information indicates that financial assistance (loan to total asset) variable is contributed significantly to the change in the productivity of the firm. This means that the loan variable can influence the productivity.

\subsection{Regression of Profitability against financial services:}

Table-4 shows a regression analysis of the profitability of SMEs against loan variable. 
Table-4:Estimates of pooled Data of Step Wise Regression Model Model-I (Dependent variable: Profitability)

\begin{tabular}{|c|c|c|c|c|c|}
\hline \multicolumn{6}{|c|}{ Model-I (Dependent variable: Profitability) } \\
\hline Details & $\mathbf{B}$ & S.E & t value & Sign & VIF \\
\hline Constant & 2.447 & .706 & 3.89 & $.002^{*}$ & \\
\hline Loan to T.A & .25 & .13 & 1.92 & .001 & 1.24 \\
\hline Size & .175 & .114 & 1.053 & $.001^{*}$ & 1.38 \\
\hline Age & .16 & .13 & 1.34 & $.456^{* *}$ & 1.15 \\
\hline Relationship banking & .08 & .11 & .73 & .345 & 1.04 \\
\hline T-bond rate & .15 & .13 & $\mathbf{1 . 1 5}$ & .023 & 1.22 \\
\hline F value & 1.92 & & & $.002^{*}$ & \\
\hline $\mathbf{R}^{2}$ & $63.0 \%$ & & & & \\
\hline Adjusted R' & $37.3 \%$ & & & & \\
\hline
\end{tabular}

Note: Data have been compiled by the researcher

$* 1 \%$ level of significance, $* * 5 \%$ level of significance

Table-4 shows a regression analysis of the profitability of SMEs against loan variable and other control variable. The table shows that the co-efficient of determination of the linear regression of profitability against the loan is explained by $63.0 \%$ percent of the variation for the sample SMEs. It is also revealed that the results of ' $F$ ' test and ' $\mathrm{T}$ ' statistics were found highly significant. The parameter information shows that loan to total assets ratio i.e. financial assistance contributed significantly to the relationship with change in profitability of the assisted firms. This means that the loan variable can influence the profitability.

\section{Effect of Financial Assistance :( Qualitative Analysis)}

Table-5 provides a summary of these responses. It is evident from the table that most of the respondents, 47.26 percent started/restarted their enterprises as a result of receiving financial help. The volume of production/sales was increased by about a fifth, 17.29 percent of the respondents, while the same percentage of the entrepreneurs increased working capital.

Table-5: Types of changes Made as a result of Receiving loan

\begin{tabular}{|l|l|l|}
\hline \multirow{2}{*}{ Multiple Response category } & \multicolumn{2}{c|}{ Financial Support $\mathbf{n}=41$} \\
\cline { 2 - 3 } & No & \% \\
\hline Restarted / Started firms & 19 & $\mathbf{4 7 . 2 6}$ \\
\hline Increased production/Sales & 10 & $\mathbf{2 4 . 0 6}$ \\
\hline Increased working capital & 7 & $\mathbf{1 7 . 2 9}$ \\
\hline Purchased machinery & 3 & 7.63 \\
\hline Expanded business & 2 & 3.76 \\
\hline Improved Production process & - & - \\
\hline Improved Product quality & - & - \\
\hline Others & \multicolumn{2}{|}{} \\
\hline Total & 41 & 100 \\
\hline
\end{tabular}

Source: Field Survey

The survey results are exhibited in Table-5. It is revealed that a few respondents, 3.75 percent, thought that their volume of production/sales would have been lower without such help. Important to note that, a total of 56.39 percent of the owner/managers under study mentioned that they would not have survived or re-started their business, whilst 10.53 percent would have had to defer their projects without the financial help received. About 11.28 percent of the respondents would not have bought machines if they had not received loans.

\section{Conclusion}

The present study evaluates the entrepreneurship development of the sample enterprises through some variable suggested by Mathew (2009), viz., sales growth, return on investment, assets turn over, and profit margin. From the above analysis, it can be concluded that by taking loans from BASIC bank, the sample enterprises have been able to increase their sales, profit, assets, and the like, through proper utilization of the finance. Both quantitative and qualitative analyses were carried out. Accessibility to banks loans, no matter the magnitude, significantly affects firm's performance. Four aspects of performance were considered profitability, sales and number of employee and productivity. The results show that firms that receive banks loans significantly increase their performance.

\section{Reference}

Akhter, W. and Alauddin, M. (2016), "An Assessment of the Contribution of Private Commercial Banks to the Growth of Small and Medium Enterprises in Bangladesh", IOSR Journal of Business and Management 
(IOSR-JBM), Vol.18, Issue-5, pp.26-33.

Akterujjaman, S.M. (2010), "Problems and Prospects of SMEs Loan Management: A study on Mercantile Bank Ltd. Khulna Branch" Journal of Business and Technology (Dhaka), vol. v, Issue-02, pp-38-52.

Ahmed, M. and Chowdhury, T.A. (2009), "Performance Evaluation of SMEs of Bangladesh," International Journal of Business and Management, Vol.4, No.7, pp.126-133.

Afrin, S. , Islam, N. and Ahmed, S.U. (2008), "A Multivariate Model of Micro Credit and Rural Women Entrepreneurship Development in Bangladesh", International Journal of Business and Management, Vol.3, No.8.

Alam, S. and Ullah, A. (2006), "SMEs Bangladesh and Their Financing: An Analysis and Some Recommendations." The Cost and Management, vol. 34, No. 3, pp-57-72.

Birky, S and Westhead, P (1990) "Growth and Performance contrast between types of small Firms", Strategic Management Journal, Vol. II, pp.535-557.

Bosri, R. (2016), "SME Financing Practices in Bangladesh: Scenario and Challenges Evaluation”, World Journal of Social Sciences, Vol.6, No. 2, pp.39-50.

Bose, T.K. and Uddin, M.R.U. (2013), "Factors Affect the Success of SME in Bangladesh: Evidence from Khulna City", Journal of Management and Sustainability, Vol.3, No.3, pp.166-172.

Brooksbank, R., Kirby, A. and Wright, G. (1992), "Marketing and Company Performance: an examination of medium sized manufacturing firms in Britain", Small Business Economics, Vol. 4, pp.221-236.

Brown, J. L. and Howard, L.R.(1982), "Managerial Accounting and Finance",London: The English Book Society and McDonald and Evans Ltd. pp.814-820.

Chowdhury, M. and Alam, Z. (2017) "Factors Affecting Access to Finance of Small and Medium (SMEs) of Bangladesh", The USV Annals of Economics and Public Administration, Vol.17, Issue-2(26), pp.55-68.

Davis, J. and Gaburici, A. (2001), “ Non Farm employment in Small-Scale enterprise in Romania: Policy and Development issues", Natural Resources Institute Report (2637), pp.20-55

Gibson, G.H. (2004), "Financial Reporting Analysis: Using Financial Information" (9 ${ }^{\text {th }}$ ed.), New York; H Corper, Collins, p.252.

Goldmark, S. and Rosengard,J. (1995), “Evaluating Small Scale Enterprise Impact-A Manual to Evaluate SSE Development Project", USAID, Report,No.6,Washington.

Grover and Singla, (2012), "Growth and Financing of SMEs: A Case Study of Punjab and Haryana", AsiaPacific Journal of Management Research and Innovation, Vol.8(3), pp315-321.

Haider, M.B. and Akhter, T. (2014), "Small and Medium Enterprises Financing in Bangladesh: The Missing Middle", International Journal of Management, Business and Research, Vol.4(4), pp. 295-308.

Hettige, H. (1992) ," Towards Financial Deepening in Sub- Sahara Africa: An Analytical Framework", Industrial and Energy Department, Working Paper, Industry Series, World Bank, Washington, D.C. U.S.A.

Islam, A. Khan, M. A, Obadullah, A. M., and Alam, M.S., (2011) "The Effect of Entrepreneur and Firm Characteristics on the Business Success of Small and Medium Enterprises (SMEs) in Bangladesh," International Journal of Business and Management, vol. , No. 3, pp.289-299.

Jahur, S. (2010), "Determinates of Success of Failure of Entrepreneurs of SMEs in Bangladesh: An Explorative Study." Seminar Proceedings in Transition of Entrepreneurship to the Next Generation," Faculty of Business Administration.

Little, I.M.O. (1988), “ Small Scale Industries in Developing Countries : Empirical Evidence and Policy Implications", MSU, International Development, No.9 East Lansing, Michigan.

Mathew, V. (2009), "Sustainable Entrepreneurship in Small- Scale Business: Application, Concepts and Cases", The ICFAI, University Journal of Entrepreneurship Development, Vol. VI, No.1, pp.41-61.

Mamun, A., Hossain, M. and Mizan, A.N.K.,(2013), "Involvement of Banks in Small Enterprise Financing: Problems and Issues for Bangladesh", Conference Proceedings, Organized by Bangladesh Institute of Bank Management, pp.143-153.

Obamuyi, T.M. (2010), “Firm's Performance and Lending Constraints in Nigeria”, The Journal of Entrepreneurship ,SAGE Publication, Vol. 19 pp. 179-190.

Pandey, N. and Ansari, M.A. (2012), "Role of Financial Institutions in the Development of Women Entrepreneurship, Indian Research Journal of Extension Education, Special Issue, Vol. 1, pp. 279-288.

Somoye, R. O. C. (2013), "The Impact of Finance on Entrepreneurship Growth in Nigeria: A Cointegration Framework", ACRN Journal of Entrepreneurship Perspectives, Vol.2, Issue-2, pp.21-45.

Sharma, S. C. (2012), "Institutional Support Functions to Small Entrepreneurs in India”, International Journal of Research in IT and Management, Vol. No.2, Issue-2, pp.1007-1017.

Solaiman, M. and Chowdhury T. (2010) "Development of Small Industries in Bangladesh, An Analysis From Managerial Excellence and Strategically Marketing Context" Asian Affairs, vol. 30, No. 1, pp-21-31

Taiwo, J.N. , Falohun, T.O. and Agwu, M.E. (2016), "SMEs Financing and its Effect on Nigerian Economic Growth”, European Journal of Business, Economics and Accountancy, Vol.4, No.4, pp.37-54. 